\section{Is there more to me than soccer? Impact of a career-ending injury}

\author{
Frederikke Pultz Madsen (1)
}

\section{THE BEGINNING}

When I was a little girl, I would watch my dad play soccer, and I remember wanting to be just like him. I was thrilled when I joined the local team at age 6 . From that moment, and for many years to come, my whole life revolved around soccer. As my passion intensified, I decided to take my game to the next level. I moved to an elite soccer club. I was excited about the new environment and rapidly became an integral part of the team.

\section{SHATTERED DREAMS}

Elite athletes experience aches, but as I tried to push through the pain, I eventually knew something was not right. I began to experience a slight pain in my left groin. At first, I figured it was due to overuse, but over time, the pain persisted and worsened. Quickly, it evolved from a mild groin pain to a horrendous hip pain. I went to see my physical therapist, but it was still unclear what the problem was. I was told to take a few weeks off from practice in order to fully recover. Unfortunately, that did not help. My parents brought me to see different kinds of specialists; however, none of them were able to pinpoint the problem. It seemed impossible for me to ever play again. After a couple of months, the pain hindered my ability to complete simple, everyday tasks. Sitting in a chair, going for a walk and regular stuff like that were painful. The whole situation was taking a serious toll on my mood and mental health. After careful consideration, I saw no other option than to quit soccer altogether.

\section{LOSS OF IDENTITY}

Grief is a natural response to loss. The day I stopped playing soccer at an elite level, I lost my identity and what I thought would be my life's purpose and greatest dream. I had so much sadness and anger bubbling up inside me. For about 10 months, nobody around me was aware of how truly devastated and depressed I was. I woke up in the morning, went to school, went home, did my homework and went to bed. During this time, I focused all my energy on my schoolwork, striving for

Center for General Practice, Aalborg University, Aalborg, Denmark

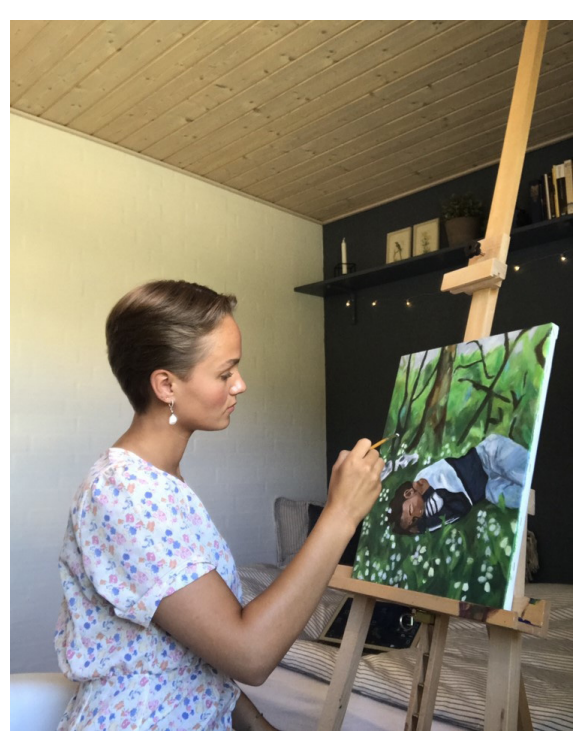

Figure 1 Frederikke Pultz, working on my acrylic painting.

good grades. I was trying to fill the empty hole in my heart, now that soccer was no longer a part of my life.

\section{DIAGNOSIS OF STRESS AND DEPRESSION}

10 months had gone by. I was consistently trying to fix the bleeding wound inside of me, but to no success. In mid-December 2018, I finally collapsed in tears. I was writing a school assignment due the following day. I had spent all day trying to finish it, but I had only written a couple of lines. I was struggling to stay focused. I had a horrible headache and could not think straight. In retrospect, this particular day proved to be a major turning point in my life. It all went downhill from there, to put it mildly. From one day to another, my whole world collapsed. To make matters worse, my doctor diagnosed me with stress and mild depression. He advised me to stay home from school to ease the stress. I did not go to school for 4 months. I cried almost every day. I had a hard time dealing with the stigma attached to stress and depression. I had lost all hope and faith in my future. Luckily, my mom and dad took me to see a therapist. She was amazing and I am forever grateful for meeting her. Together, we uncovered the underlying problem causing my mental illness. Talking to her gave me an immediate sense of relief that I was not alone. It was a problem shared by others. This brought a sense of both comfort and hope. I no longer felt embarrassed about having a mental health condition. Instead, I decided to speak openly about my situation, which turned out to be essential for my recovery. Furthermore, she introduced me to meditation, which changed my life for the better. I began feeling comfortable with my mind, as I learnt to observe my thoughts and feelings without judgement. I went to therapy sessions every other week and finally began to see light at the end of the tunnel.

\section{HIP LABRAL TEAR}

I started feeling better mentally, but I was still suffering from a hip injury that had caused all the trouble in the first place. In the spring of 2019, I decided to request both an MRI scan and an X-ray scan from my doctor, through which it was determined that I suffered from a hip labral tear. Words cannot describe the relief I felt. After 2 years of not knowing what had caused the agony in my hip that led me down that miserable path, I finally had an answer. I burst into tears, I remember, finally knowing that something could be done. I had surgery in January 2020. I was told hip labrum surgery recovery takes at least 8-10 months in most cases, before you get back to your normal, active lifestyle. By now, it has been 4 months since I had my surgery. The physical therapy team at the hospital helps me through every step of the rehabilitation process. I make sure to stick to my recovery plan and attend all of my follow-ups. I am positive that my recovery will be successful.

\section{BACK TO THE DRAWING BOARD}

As the Danish philosopher, Søren Kierkegaard, once said, "Life can only be understood backwards, but it must be lived forwards". The same applies to me. I consider these past 2 years the hardest years of my life. Still, I can say without a shadow of a doubt, I would not trade them for anything. It was a blessing in disguise that changed my life. For better of worse, I was forged to connect with myself on a much deeper level. I kept practising the skill of meditation as a substantial part of my recovery, and it did wonders reducing my stress, anxiety and depression. In the autumn of 2019, I went back to school; only this time I went to an art and writers' school. There, I found my courage, and I truly 
blossomed. I realised that there is more to life than soccer. There is more to me than soccer. I began writing, drawing and painting, which gave me great pleasure and a newfound sense of inner peace. I continue to use creative arts as therapy. This summer, I am going back to school to study, and I cannot wait.

\section{TWO BITS OF ADVICE FOR A CLINICIAN} WORKING WITH AN ELITE ATHLETE

1. Acknowledge the importance of an injured athlete's mental health. How athletes respond to injury may differ, and there is no predictable sequence or reaction. When suffering an injury, there are two parts of recovering. One part of recovery is the physical, and then, there is the mental aspect of recovery. More often than not, people forget they need to recover mentally from the ways their injury affected their mental state-and that healing goes far beyond just physical.

2. Provide psychological therapy to athletes who are forced to quit their sport due to severe injury. A sudden end to an athletic career is what often pushes people into depression and anxiety. In many cases, the former athlete will need guidance in order to find a new path in life.

Collaborators BPT, MSc, Kristian Lyng, Center for general practice at Aalborg University. Michael Skovdal Rathleff, Center for General Practice at Aalborg University.

Contributors FPM is the sole author of this piece. $\mathrm{KL}$ and MSR supported with editing and submission. The article is about the author's experience as a patient and the author gives full permission for this article to be published.
Funding The authors have not declared a specific grant for this research from any funding agency in the public, commercial or not-for-profit sectors.

Competing interests None declared.

Patient consent for publication Obtained.

Provenance and peer review Not commissioned: internally peer reviewed.

(c) Author(s) (or their employer(s)) 2020. No commercial re-use. See rights and permissions. Published by BMJ.

\section{Check for updates}

To cite Madsen FP. Br J Sports Med 2020;54:1440-1441.

Accepted 15 July 2020

Published Online First 21 August 2020

Br J Sports Med 2020;54:1440-1441.

doi:10.1136/bjsports-2020-102843

\section{ORCID iD}

Frederikke Pultz Madsen http://orcid.org/0000-00021485-2488 